\title{
Prostate Cancer Stem Cells: Do They Have a Basal or Luminal Phenotype?
}

\author{
Norman J. Maitland • Fiona M. Frame • \\ Euan S. Polson • John L. Lewis • Anne T. Collins
}

Published online: 4 January 2011

(C) Springer Science+Business Media, LLC 2010

\begin{abstract}
The prostate is a luminal secretory tissue whose function is regulated by male sex hormones. Castration produces involution of the prostate to a reversible basal state, and as the majority of prostate cancers also have a luminal phenotype, drug-induced castration is a front line therapy. It has therefore been assumed that the tumor arises from transformation of a luminal progenitor cell. Here, we demonstrate that a minority basal "cancer stem cell" (CSC) population persists in primary human prostate cancers, as in normal prostate, serving as a reservoir for tumor recurrence after castration therapy. While the CSCs exhibit a degree of phenotypic fluidity from different patients, the tumorinitiating cells in immunocompromised mice express basal markers (such as p63), but do not express androgen receptor (AR) or markers of luminal differentiation (PSA, PAP) when freshly fractionated from human tissues or following culture in vitro. Estrogen receptors $\alpha$ and $\beta$ and AR are transcriptionally active in the transit amplifying (TA) cell (the progeny of SC). However, AR protein is consistently undetectable in TA cells. The prostate-specific TMPRSS2 gene, while upregulated by AR activity in luminal cells, is also transcribed in basal populations, confirming that AR acts as an expression modulator. Selected cells with basal phenotypes are tumor initiating, but the resultant tumors are phenotypically intermediate, with focal expression of AR, AMACR, and p63. In vitro differentiation experiments, employing lentivirally transduced SCs with a luminal (PSA-probasin) promoter
\end{abstract}

N. J. Maitland $(\bowtie) \cdot$ F. M. Frame $\cdot$ E. S. Polson · J. L. Lewis •

A. T. Collins

YCR Cancer Research Unit,

Department of Biology (Area 13), University of York,

Heslington,

York YO10 5DD, UK

e-mail: n.j.maitland@york.ac.uk regulating a fluorescent indicator gene, confirm that the basal SCs are the source of luminal progeny.

Keywords Prostate $\cdot$ Stem cells $\cdot$ Basal $\cdot$ Luminal .

Differentiation

\section{Introduction}

Human prostate cancer is primarily a disease of the luminal secretory epithelium in the prostate gland. In normal prostate, luminal cells can be identified by expression of androgen receptor (AR), polyamines, differentiationspecific cytokeratins, prostate-specific antigen (PSA), and prostatic acid phosphatase (PAP) [1]. Indeed, PSA and PAP have been exploited as diagnostic and monitoring tools for prostate cancer, although their ability to distinguish malignant disease is not perfect $[2,3]$. Even when prostate cancer returns in castration resistant form, after failure of hormonebased therapies, elevated serum PSA levels remain an excellent indicator of tumor progression [4].

However, studies of prostate cancer both in the laboratory and in patients are plagued by the presence of heterogeneity. Phenotypic markers are frequently expressed in disparate patches across the tumor, and within a single prostate gland there is clear evidence from both genetic and phenotypic studies for the presence of multiple areas of tumor histology, sometimes with different clonal origins [5, 6]. The response of the tumor to common chemotherapies, employed after failure of hormone therapy, is difficult to predict and has a relatively limited duration [7]. The source of this heterogeneity is presently uncertain. "Field cancerization", where a proportion of the prostate is activated for transformation into a cancer phenotype has been proposed as a mechanism, in a similar manner to that for oral cancers 
[8]. There is also the possibility of distinct independent events. This has been best marked by the detection of microsatellite instabilities/loss of heterozygosity $[5,9]$ and most recently and most usefully by the presence of fusion genes. The most common fusion is between the TMPRSS2 prostate-specific gene and the proto-oncogene (ETS family member) ERG [10], which is most frequently formed by a deletion within chromosome 21, bringing ERG gene expression under the direct control of the TMPRSS2 gene promoter [11]. TMPRSS2 is considered to be one of the most highly prostate-specific genes [12] and has been shown in previous studies to be potently up-regulated by the presence of male sex hormones. The role of the fusion gene in oncogenesis (apart from the properties deriving from the over-expressed oncogenic ERG protein) has not yet been fully established, although experimental evidence for loss of growth control by over-expression has been demonstrated [13, 14]. Recent evidence suggests that the fusion can be generated, even in $\mathrm{AR}^{-}$cells, by prolonged exposure to androgens $[15,16]$.

The origin of prostate cancer and the cell type of origin remains controversial (as shown in Fig. 1). The simplest etiological mechanism would be a direct transformation of normal luminal cells into the luminal phenotype of the treatment-naïve primary cancer, as shown at the top of Fig. 1. This presupposes that prostate cancer induction is a stochastic homogeneous event, producing homogeneous progeny, i.e., a single transformation event, which results in a mass of tumor cells with loss of growth control. Evidence from other tumor types, most notably from the hematopoietic system [17], suggests that a hierarchy of cells exists within a cancer. This hierarchy is of course dominated by one cell type in prostate, which is likely to be an aberrantly growing luminal cell. However, the hypothesis that each tumor is driven by and perhaps initiated from a stem celllike population with very different phenotypic properties from the tumor mass is now receiving more consideration $[18,19]$.

Cellular Organization and Hierarchies in the Prostate The normal human prostate consists of two distinctive epithelial layers: a basal epithelium, which adheres to and signals via the basement membrane, and a luminal epithelium, which is separated from intact basement membrane by the basal layer (inset Fig. 1). In contrast, mouse prostate consists mainly of a luminal-like epithelium, which contains occasional basal cells, but with luminal cells in direct contact with the basement membrane [20]. Basement membrane (BM) itself is a complex entity made up of a number of different structural proteins, adhesion molecules, and growth factors, and as such it provides a barrier between the epithelial layer and the underlying stroma. BM has also been shown to play a key role in prostate development where positional signals for epithelial integrity are transmitted via the basolateral contacts of basal cells.

Prostate Stroma Prostate tissue models which lack stroma, i.e., most of those reported in the literature and used for primary therapeutic development, fail to take account of the stromal signaling factors such as FGFs and TGF $\beta$, which can directly influence epithelial cell behavior [21, 22]. During development of the embryonic prostate (in rodents), the stromal component, i.e., urogenital sinus mesenchyme (UGM), is under the influence of hormones and exerts a powerful differentiating and growth-promoting influence on the vestigial epithelium within the prostate. UGM was shown in the classical experiments of Cunha et al. [23] to define organogenesis in a way which previously had been thought impossible: female epithelium from the ovary in the presence of UGM can be differentiated to form a morphologically distinguishable prostate gland in a heterotypic graft [23]. In development of the murine prostate, these initiated cells could be considered to be tissue stem cells, although their embryonic nature suggests they may well require further stimuli to acquire full prostate tissue definition or restriction.

In man, the content and phenotype of stromal cells in mature prostate is quite distinctive from that in the mouse. The stromal cells are more numerous and consist of a mixture of cell types, some of which have a smooth muscle phenotype (as in breast cancer) and express AR, acting as a potential source of the andromedins which have been proposed to be secreted by the UGM in the developing mouse prostate under the influence of the androgens [24, 25].

Epithelial Stem Cells in Normal Mouse and Human Prostate The nature of the mouse stem cell in an adult prostate remains the subject of some controversy. In a series of experiments in 2008, Leong et al. [26] showed that a single basal cell type $\left(\mathrm{CD} 117^{+}\right)$had the capacity to develop into a mouse prostate when xenografted under the appropriate conditions. More recently, however, Wang et al. [27], using strains of genetically manipulated mice, proposed an alternative stem cell, one that is $\mathrm{Nkx} 3.1^{+}$but can survive under castrate conditions and comprises $1 \%$ of all cells in the mouse prostate. These cells did not express typical basal cell markers and were therefore defined as a luminal stem cell. However, if one defines the stem cell as being able to reconstitute a complete glandular structure, then the existence of two "stem cells" is difficult to reconcile and may simply reflect our definition of a basal or luminal cell, which is based on expression of certain markers. As with most systems, there is heterogeneity in expression, and it is more likely that the murine stem cell can be classified as intermediate between a basal and luminal cell.

In human prostate, the evidence is now very strong for the existence of a primitive epithelial cell that is present 


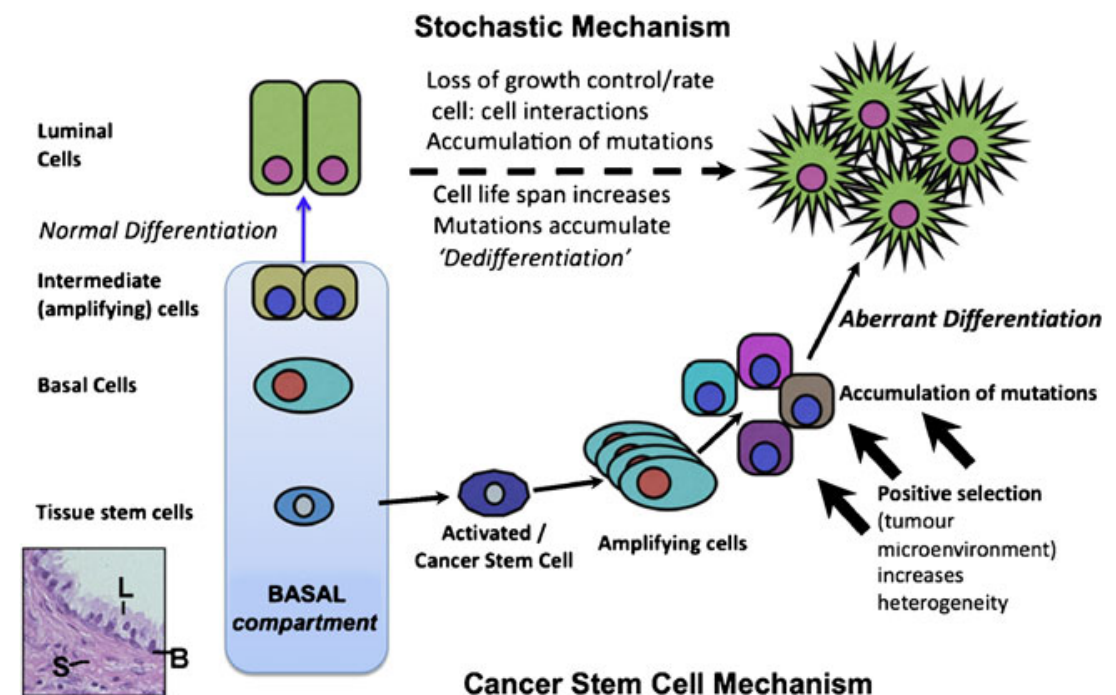

Fig. 1 Normal human prostate and the origins of human prostate cancer. Two alternative pathways to develop human prostate cancer are illustrated: (1) stochastic conversion of luminal cells and (2) a stem cell mechanism. A stem cell representation of differentiation in the normal prostate is shown on the left of the figure, with a histology image of a normal prostate gland shown in the inset ( $B$ basal cells, $L$ luminal cells, $S$ stroma) within the basal compartment as the tissue stem cell for prostate $[28,29]$. A number of markers have been used to identify the normal SC, and there is consensus that they have high levels of (1) integrin expression (e.g., $\alpha_{2} \beta_{1}$, at high levels mediating attachment to collagen type 1) [28] (2) CD44 (which is predominantly basal and which has multiple functions, but acts as a receptor for hyaluronic acid) and in our laboratory [30] the CD133 antigen, which has no discernable function to date, but serves as a stem cell antigen in many tissues (recently reviewed in [31]) and as an enrichment factor in prostate [30]. The sub-fractionation identifies a cell population with high colony-forming efficiency in vitro but also the ability to reconstitute prostate glands in immunodeficient mice, accompanied by differentiation into $\mathrm{AR}^{+}$, PSA-expressing luminal cells [30]. Complete differentiation both in vitro [28] and in vivo [30] also required the presence of prostatic stromal cells and active basement membrane, such as matrigel. Thus, the normal stem cell for prostatic gland formation is firmly established in a basal "niche".

The existence of an epithelial stem cell in normal prostate could imply the existence of a progenitor cell for prostate cancer. There is good evidence from several other cancer types that the most primitive cell can be the target for oncogenesis. Whether indeed it is the stem cell itself or a cell that has reverted to a stem-like phenotype, perhaps under the influence of gene activation, as shown elegantly for iPS cells [32, 33], is still open to conjecture.

Cancer Stem Cells in Human Prostate Cancer In human prostate, the nature of the "cancer stem cell", perhaps better termed the tumor-initiating cell (TIC), remains somewhat controversial. Since our laboratory's identification of highly invasive epithelial cells with high clonogenicity from primary cultures of human prostate cancers [34], which were characterized by the cell surface markers that we had previously employed to isolate normal tissue stem cells from non-malignant prostate [30], other candidate cells from both mouse [27] and human [35-39] systems have been proposed. The significance of the CD133 marker is a particular source of controversy probably on two grounds: firstly the expression of CD133 is critically determined by cellular microenvironment; transcription can be modulated by hypoxia [40], and different splice variants/transcriptional initiation sites are seen in many different tissues [41]. In prostate, there is a preferential transcriptional start site which we, and others, have quantified in cells and tissues (Pellacani et al., submitted for publication). In cell cultures, CD133 expression is critically determined by the culture media, as the presence of serum and even $10 \mathrm{nM} \mathrm{Ca}^{++}$have a significant influence on methylation status such that increased serum correlates with decreased expression. Secondly, the technical difficulties of using the various commercial CD133 antibodies [some of which do not bind the glycosylation (stem cell) specific epitope], coupled with the relative rarity of the SC in primary tissue biopsies, results in low cellular yields, which are in fact a demonstration of the rarity of the CSC $(0.1 \%)$ within a heterogeneous tumor mass.

The question of cellular yield versus purity is also critical in phenotypic analysis of cellular subsets. For some biological assays, the functional cells are "self-selecting" (e.g., clonogenicity or invasion of matrigel/collagen matrices), but even a small contamination can skew the results of gene expression 
profiling [42]. Cell purity is an important consideration for the question we address in this manuscript: Do SCs in a largely luminal epithelial tumor have a similar luminal phenotype or do they have a basal nature with the capacity to differentiate into luminal cells (Fig. 1)?

\section{Results}

Expression of Basal Cell Markers in Fractionated Prostate Cancer Epithelial Cells As shown in Fig. 2a, human prostate biopsies can be fractionated into component cell parts as first described for normal prostate [30]. When applied to malignant prostate tissues, the same cellular fractions can be identified but in differing proportions [34]. In cancers, there is a much larger population of luminal/ intermediate cell types, which express AR and, in contrast to the normal situation [43], are highly proliferative. In addition to this population, there is also an underlying low abundance basal cell population which comprises less than $1 \%$ of the tumor mass and can be isolated on the basis of CD44 expression, high expression of $\alpha_{2} \beta_{1}$ integrin complex (by rapid adhesion to collagen) and, for the stem cell
Fig. 2 Fractionation of human prostate biopsies: phenotype of isolated stem cell fractions. a Cell fractionation to enrich for stem cell $\left(\alpha_{2} \beta_{1}{ }^{\mathrm{Hi}} / \mathrm{CD} 133^{+}\right)$and committed basal/precursor cells $\left(\mathrm{CD} 44^{+} / \alpha_{2} \beta_{1}^{\text {Low }}\right)$ as used to generate expression profiles in Birnie et al. [42]. A transit amplifying population $\left(\mathrm{CD} 44^{+} /\right.$ $\alpha_{2} \beta_{1}{ }^{\mathrm{Hi}} / \mathrm{CD} 133^{-}$) can also be retrieved during this fractionation. b Immunophenotype of $\left(\alpha_{2} \beta_{1}{ }^{\mathrm{Hi}} / \mathrm{CD} 133^{+}\right)$cells from a hormone naïve Gleason grade $4+$ tumor with respect to common epithelial differentiation markers. c Nuclear p63 detection (green) in SC-derived colony from cancer biopsy. Nuclei counterstained (blue) with DAPI. d Detection of cytoplasmic AMACR (green) in epithelial colonies derived from prostate CSCs by immunofluorescence. Nuclei are counterstained with DAPI (blue) a

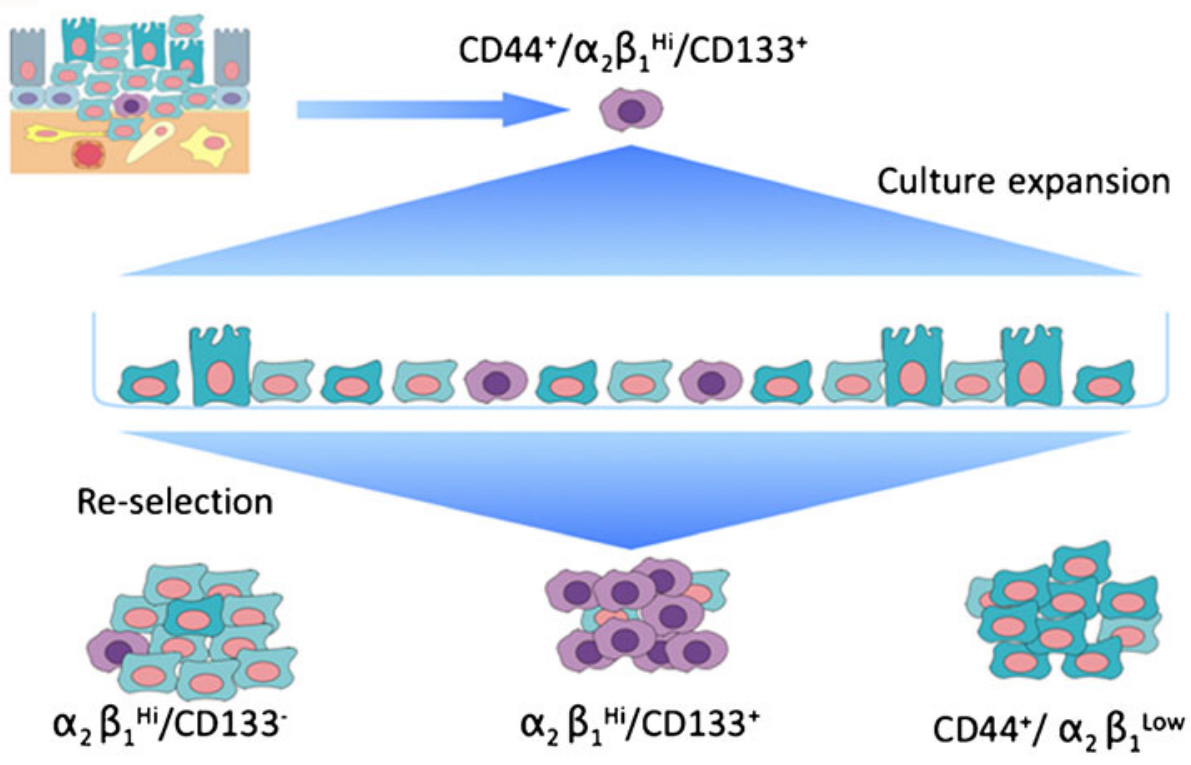

Transit Amplifying Cells

Stem Cell Enriched

Committed Basal Cells

b
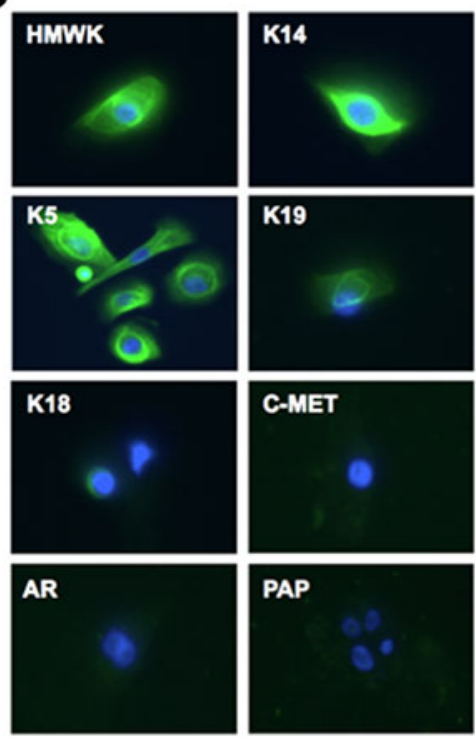

C
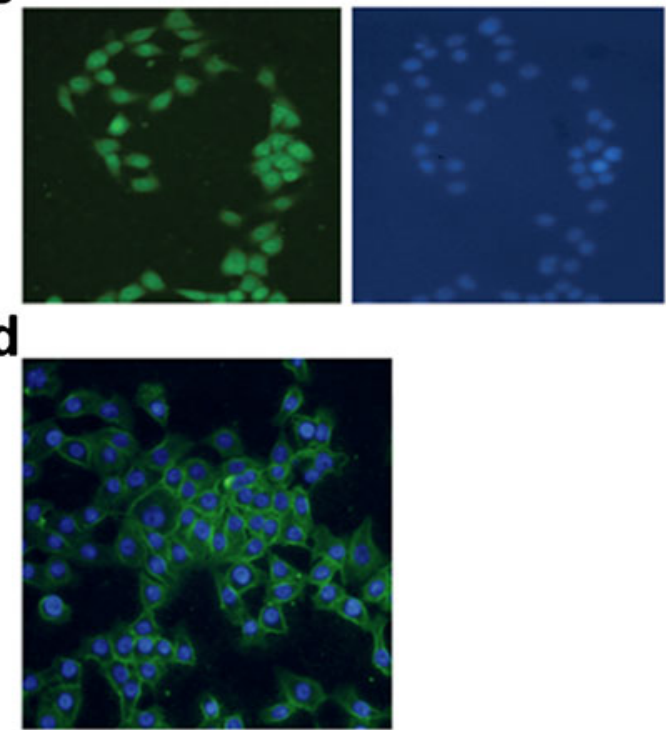
fraction, immunomagnetic selection for the CD133 antigen. When the different fractions are phenotyped according to protein expression, it is clear that there is a high prevalence of basal markers (as shown in Fig. 2b) in the SC and TA $\left(\mathrm{CD} 44^{+} / \alpha_{2} \beta_{1}\right.$ high $\left./ \mathrm{CD} 133^{-}\right)$cells when compared to the luminal fraction. Other basal markers expressed within the SC and TA populations include p63 (Fig. 2c), which is present within the nucleus of these selected cells [44]. The cytokeratin pattern of the SC and TA populations is also characteristic of a basal phenotype, expressing cytokeratins 5,14 but occasionally within the cancers more luminal cytokeratin 18 expression has been observed. No expression of AR, PSA, or PAP is observed in the selected CSC population (Fig. 2b) although the prostate cancer marker AMACR [45] is expressed in cultured cells (Fig. 2d).

This basal phenotype is reinforced by data abstracted from [42] in which a total gene expression profile was carried out on the constituent cell populations from both normal and tumor tissues. Here, the cell differentiation markers expressed in the CSC population were again predominantly basal. It should be noted, however, that such cell fractionation of primary tissues before in vitro culture selection occasionally yields a para-luminal phenotype. In these cases, a further FACS analysis of the "purified cell population" indicated a low percentage of cells with luminal phenotype, which had failed to be depleted in the original fractionation. Even a $1 \%$ contamination of the SC fraction by luminal cells is sufficient to produce an apparent over-expression of luminal markers, such as AR and PSA, whose transcription levels are at least 3,000-fold higher and as quantified below (Fig. 5c) can be over-expressed up to 500,000-fold. Such low level contaminations were also observed in the microarray heat maps where differentiated cell "breakthrough" was apparent in a direct comparison of the different cell types [42]. This is mainly a feature of freshly fractionated tissues where insufficient breakdown of the complex tissue structure has occurred.

Oncogenic Potential of Epithelial Sub-fractions of Prostate Tumors In our original studies, the SC population showed the highest secondary colony-forming efficiency, in keeping with its ability to found new growth in vitro and indeed tumor growth in vivo [34]. The cancer phenotype of these cells was further confirmed by two separate methods. Firstly, needle biopsies of the same tumor were capable of forming cancers in immunocompromised mice. For prostate, such assays have exhibited a relatively low "take rate" of such primary material relative to other organ systems. In our current studies, we have shown (see Table 1 and Fig. 3) that the tumorigenicity of such tissue fragments is limited, even in the $\mathrm{Rag} 2^{-/}$gammaC $^{-/}$mouse strain, which lacks natural killer cell activity. Strikingly, only tumors which contained a Gleason pattern 4 were capable of inducing cancer with any frequency. Lower Gleason grade cancers and benign prostatic hyperplasia samples were nontumorigenic after subcutaneous and indeed renal capsule/ orthotopic inoculation (data not shown). The invasive capacity was also demonstrable in vitro by a modified Boyden chamber assay previously described in Collins et al. [34] in which prostate stromal conditioned medium was used as a chemoattractant for freshly isolated epithelial cells from human prostate biopsies. In this assay, cultures derived from a $\mathrm{CD}_{13} 3^{+}$enriched stem cell fraction was approximately three times more invasive than the most invasive prostate epithelial cell lines such as PC-3M, and $>20$-fold higher than non-malignant cell lines and primary cells.

Expression of EMT Markers in Prostate Cancer Epithelial Cells Invasive capacity has frequently been associated with the epithelial mesenchymal transition (EMT), which has recently been shown in studies of cancer stem cells from other tissues, particularly in breast cancer [46, 47], where the CSCs also share an EMT phenotype. On examination of the cancer stem cell phenotype according to Birnie et al. [42], a number of markers of the mesenchymal phenotype were observed within the cancer stem cell expression pattern relative to $\mathrm{SCs}$ from benign prostatic tissues. In particular, loss of E-cadherin and activation of both vimentin and SPARC (osteonectin) were detected at both the mRNA and protein levels. These markers co-segregate with the basal phenotype of the CSCs. We had previously observed high levels of vimentin, a strong indicator of EMT transition in our primary cultures of high grade $\mathrm{CaP}$ [48], and immunohistochemistry of invading xenografts also coexpressed epithelial markers and vimentin (Fig. 3c, d).

Transduction with Epithelial Lineage Tracking Lentiviruses A more convincing demonstration of a stem cell is the capacity to differentiate into its potential daughter cells, e.g., luminal cells in the normal prostate. Other systems have used lineage-marking techniques to identify different subpopulations. We generated a series of lentiviruses, which contained either constitutively active promoters (Fig. 4a) or "prostate specific" promoters targeted to individual cell populations including stem cells, their daughter cells, and the ultimate luminal phenotype (Fig. 4a, b) [49, 50]. A good example of a differentiation-regulated promoter is the synthetic PSA-probasin promoter [51] where promoter activity is highly restricted to the luminal cells by the addition of the human AR-responsive PSA enhancer to the prostate-specific rat probasin promoter [52]. As shown in Fig. 4c, this promoter is completely inactive in basal cell types such as P4E6 (Fig. 4c), PC3, or PNT2, but highly active in luminal cells such as LNCaP (Fig. 4b) and 
Table 1 Xenograft frequency from primary human prostate tumors

\begin{tabular}{llllll}
\hline & Total & G6 & G7 & G9 & Hormone refractory \\
\hline Incidence & $15 \%(9 / 60)$ & $0 \%(0 / 2)$ & $14 \%(2 / 14)$ & $40 \%(6 / 15)$ & $26 \%(5 / 19)$ \\
\hline
\end{tabular}

Xenografting efficiency is expressed in percent of patients (each grafted as several fragments) tested from each tumor grade with actual number of patients shown in parentheses

PC346C, which express the AR. If the hypothesis that the stem cell in prostate cancer (as in normal prostate) has a basal phenotype, then introduction of the PSA-probasin promoter into these cells would result in cells which lack fluorescence, but induction of differentiation would trigger activity of the PSA-probasin promoter and result in fluorescent cells. When primary cells were transduced with the PSA-probasin lentivirus, no expression was seen in the undifferentiated cells either before the medium switch (Fig. 4d-SCM) or in the lower epithelial layer, which remained largely basal after differentiation induction [53]. In contrast, single luminal cells emerging from the basal layer in DM (Fig. 4d) initiated PSA-probasin activity, and red fluorescence was observed. Across the whole population, approximately $0.2 \%$ of cells undergo this transition [44] in this controlled model system.
Expression of the Androgen Receptor Gene in Fractionated Prostate Epithelium The archetypal luminal gene in prostate encodes the AR, which is normally found in about $60 \%$ of epithelial cells in normal prostate glands and more highly expressed in the majority of cells ( $>99 \%)$ in hormone naïve prostate cancers. This results in extremely high levels of transcription from AR responsive genes, the best examples of which are PSA, prostatic acid phosphatase (PAP), and TMPRSS2 [54]. When AR transcription was assayed in a total genome expression analysis [42], the levels were such that they were at best under-expressed in the committed basal cell and more likely to be completely absent within the stem cell fraction. As shown in Fig. 2b, there was no evidence of AR protein expression by IF in stem cells. It was therefore important when determining the difference between the luminal and
Fig. 3 Primary xenografts generated from human prostate tissues in immunocompromised mice. a Xenograft procedure for isolated prostate epithelial cells in $\mathrm{Rag}^{-/-}$gammaC $^{-/}$ immunocompromised mice. b Liver metastases from primary prostate xenografts. c Immunohistology of xenograft tumor to confirm expression of epithelial marker (pan)cytokeratin. d Immunohistology of xenograft tumor indicating expression of EMT marker vimentin

a

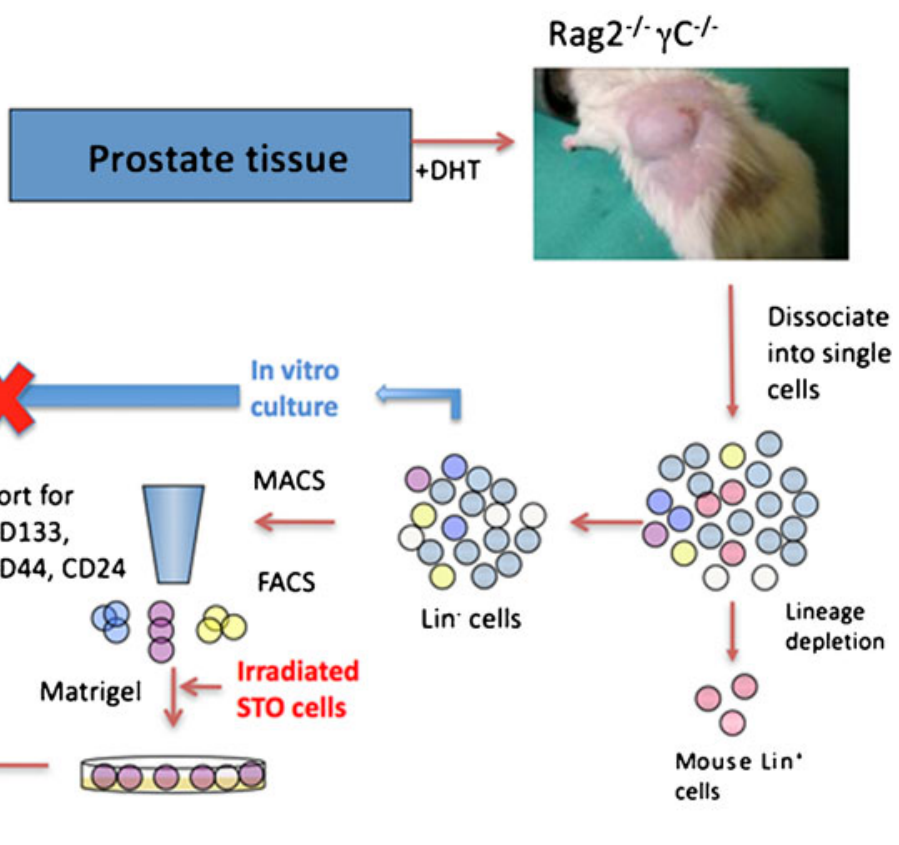

b

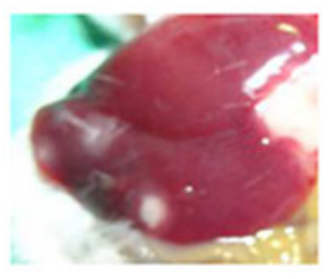

c

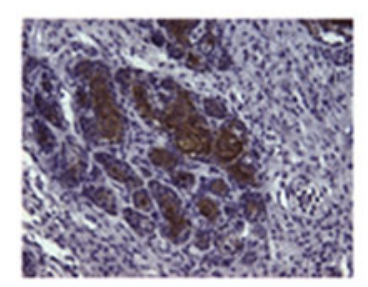

d

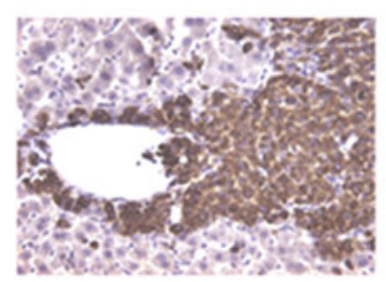


a

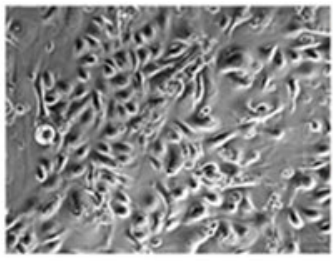

b

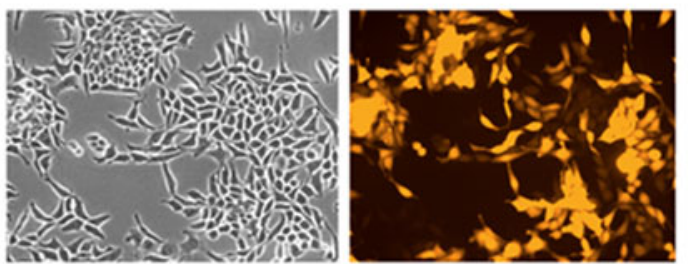

d
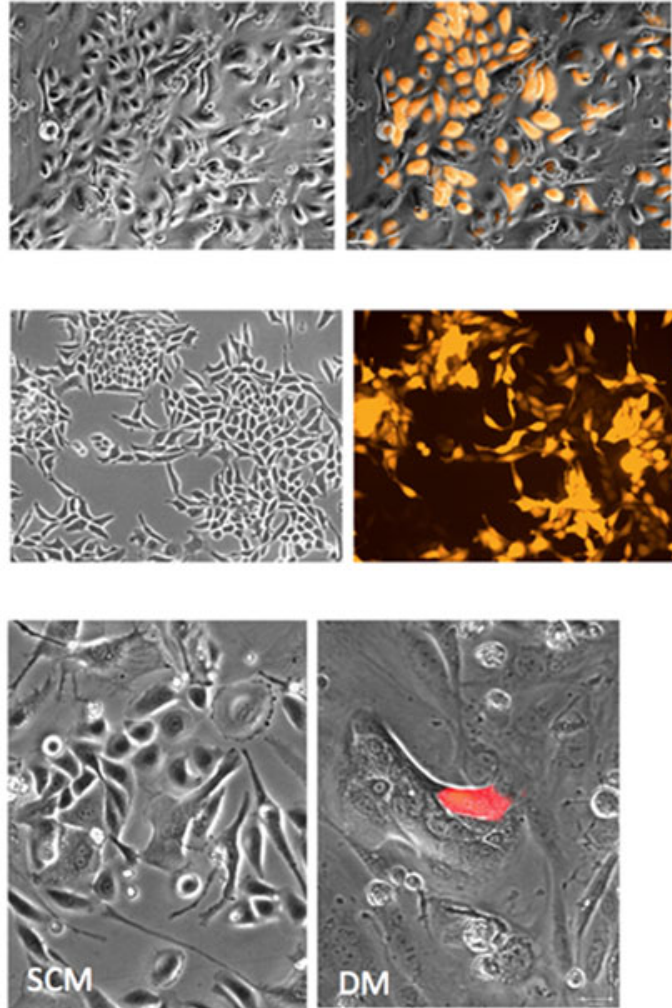

C
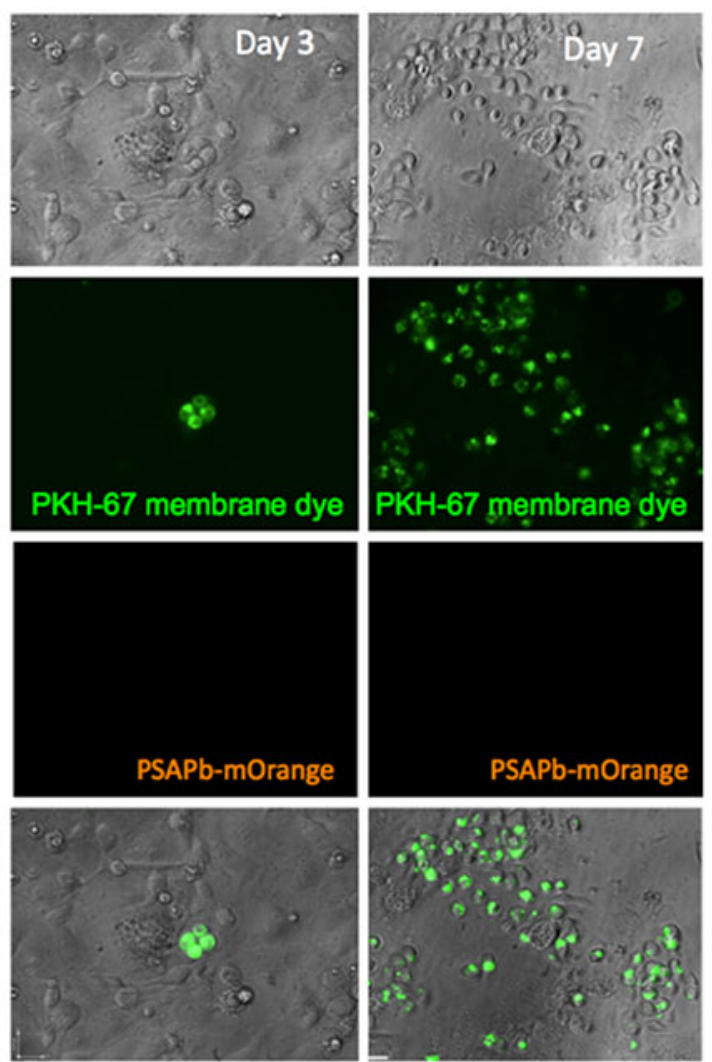

infected with PSAPb-mOrange lentivirus. d Primary prostate epithelial cells infected with lentivirus and cultured in either SCM (PSAPbCitrine lentivirus) or in DM (PSAPb-tdTomato lentivirus). Lentiviruses were optimized [49] and used to infect primary prostate cells after dissection from tissues as previously described [50].

In primary cells, following 30 cycles of RT-PCR (shown in Fig. 5d), AR expression was undetectable in every $\mathrm{CD} 133^{+}$ cell population studied. The sensitivity of the assay was such that most low copy number genes would eventually be visualized. What was more surprising was that the strongest AR transcription was detectable in the TA cells, which were derived from the original $\mathrm{CD}_{13}{ }^{+} \mathrm{AR}^{-}$cells stem cell by asymmetric division. The more differentiated $\mathrm{CD} 133^{-} / \alpha_{2} \beta_{1}$ low $\mathrm{CB}$ cells again only expressed relatively low levels of the AR. As CB cells are committed to differentiation into luminal cells where AR expression is strongest (and $>3,000$-fold higher than levels in the CB cells - data not shown), this down-regulation was unexpected. A 1:100 dilution of $\mathrm{VCaP}$ cell line cDNA is shown in Fig. 5d to reflect the difference in $\mathrm{AR}$ expression levels between the basal compartment (SC, $\mathrm{TA}$, and $\mathrm{CB}$ ) and a true luminal cell.

Expression of Estrogen Receptors in Fractionated Prostate Epithelium Estrogen receptors (ER) alpha and beta are also expressed in prostate cancer, particularly in basal epithelium [57], where it has been suggested that ER expression can substitute for AR to provide steroid response. In cells). 
Fig. 6a, expression levels of ER $\alpha$ and $\beta$ were measured in basal and luminal cell lines by RT-PCR. As found in previous studies, no ER was detectable in the luminal cancer cell lines PC346C, LNCaP, and VCaP. Weak ER $\alpha$ expression was seen in some, but not all, basal cell lines, with the strongest expression in the malignant cancer cell line PC3. All basal cells expressed detectable ER $\beta$; again, expression was highest in PC3 cells. However, fractionated epithelial cells (Fig. 6b) expressed highest levels of $\mathrm{ER} \alpha$ in the TA population, persisting in slightly lower levels in the CB cells, but no ER was expressed when the cells differentiated fully into luminal cells. Only rarely were low levels of ER ( $\alpha$ or $\beta$ ) found in SCs from normal or malignant epithelium. As TMPRSS2 expression is influenced by ER activation [58], we also looked in the same tissue cDNA preparations for both AR and TMPRSS2 mRNA. As shown in Fig. 5d, TMPRSS2 was principally expressed in $\mathrm{CB}$ cells, with lower levels in TA cells, but was undetectable in SC. In TA and $\mathrm{CB}$ cells, therefore, TMPRSS2 expression was inversely related to ER expression, although protein levels were not measured.

Phenotype of Tumor Xenografts After Inoculation of Lineage Depletion and Cell Selection The ability of fractionated populations, including the $\mathrm{CD} 133^{+}$fraction, to initiate new tumor growth was assayed by a system of limiting dilution following mouse lineage depletion, as shown in Fig. 3a. In all experiments to date, we have been unable to culture primary epithelium long term in vitro and rexenograft efficiently into recipient immunocompromised mice at any of the three grafting sites discussed earlier. However, to approach the problem, we have sought to propagate primary material in subcutaneous sites, remove the tumors, and lineage deplete the mouse component, which frequently infiltrates into these primary tumor growths. We are then able to re-graft not only total cells but also fractionated cells according to the stem cell phenotype. When this was carried out, the resultant tumors (in the absence of the inductive effects of prostate stroma) were largely of an intermediate phenotype $\left(\mathrm{CD} 44^{+} / \mathrm{CD} 24^{+}\right)$ (Fig. 7b) with focal expression of AMACR, AR, PSA, and p63 (Fig. 7a). In contrast to human tumors, clusters of cells strongly expressing the basal p63 marker were also clearly observed in xenografts even after extended passage in vivo (Fig. 7a). When xenograft tumors were lineage depleted and sorted for basal and luminal markers, tumors could be initiated from both a CD133 and CD24 phenotype. However, tumors were also derived from a $\mathrm{CD} 24^{+}$phenotype, perhaps surprisingly as high levels of CD24 expression are commonly associated with luminal differentiation. Although preliminary, tumor induction frequency remains much higher from $\mathrm{CD} 133^{+}$cells (Tables 2 and 3 ).
Fig. 5 Androgen receptor expression in prostate epithelial cell subsets. a Schematic diagram of human AR mRNA structure. The eight canonical exons of the AR gene are represented by the numbered blue boxes. Alternative, novel splice variants are represented by the orange boxes [54], the green boxes [55] and the purple linker [56] indicating a fusion between exons 4 and 8 . The binding locations of RT-PCR primers (red arrows) and TaqMan probes (blue arrows) used in our studies are also indicated. b Semi-quantitative RT-PCR analysis of TMPRSS2 and Androgen Receptor (AR) mRNA expression in a panel of prostate cell lines. PCR amplification of TMPRSS2 and AR from "normal" (PNT1a, PNT1b, PNT2c2), early- (P4E6, PC346C), and late (PC3, LNCaP, $\mathrm{VCaP})$ stage cancer and $\mathrm{BPH}-$ derived $(\mathrm{BPH}-1)$ human prostate cell lines of basal and luminal phenotypes. GAPDH was used as a loading control [42]. c Quantitative RT-PCR analysis of TMPRSS2 and Androgen Receptor (AR) mRNA expression in a panel of prostate cell lines. AR and TMPRSS2 expression levels are expressed as fold change compared to the lowest expressers (PC3 and PNT1a, respectively). All values are averages of triplicate measurements normalized to an endogenous control (HPRT) [42]. d Semi-quantitative RT-PCR analysis of TMPRSS2 and Androgen Receptor (AR) mRNA expression in human prostate primary epithelial sub-populations. PCR amplification of TMPRSS2 and AR from epithelial cultures derived from BPH (PEY089/09), cancer (PE665, PE550, PE541, PE525, PEY008/06, PEH018/09, PEH020/09), and castration-resistant cancer (PEY096/09, PEY028/07). Sub-populations consist of stem cell (SC), transit amplifying $(T A)$, and committed populations $(C P)$. $\mathrm{VCaP}$ cells were used as a positive control and GAPDH was used as a loading control

\section{Discussion}

The origins of human prostate cancer remain somewhat controversial [19, 59]. Experiments in syngeneic mouse models have provided functional data, but nevertheless the nature of the normal epithelial stem cell even in mouse remains elusive $[26,27,60]$. The elegant grafting experiments by Leong et al. [26] clearly demonstrated that single cells which have surface expression of the c-kit protooncogene (CD117) possess gland-initiating properties. The situation was complicated by Wang et al. [27], who showed that a minor population (1\%) of cells expressing the $\mathrm{Nkx} 3.1$, androgen-regulated luminal gene persisted after castration and were responsible for regeneration of the epithelial glands. This $\mathrm{Nkx} 3.1^{+}$cell was also capable of initiating cancer in mice after knockout of the PTEN gene [27]. The existence of similar dual progenitor cells is only rarely the case in other tissues; for example, the separate cells of origin for the myeloid and erythrocyte lineages have been well characterized in the hematopoietic system [61]. It would be surprising that an organ with limited epithelial complexity such as the mouse prostate should have evolved two different stem cell populations. However, the anatomy of the mouse prostate is distinctive (http:// tvmouse.compmed.ucdavis.edu/prostate/mouse/gross.html), with a multilobular structure, which may offer the potential for multiple stem cells compared to the human prostate, which has a more discrete glandular structure. For example, the distal ducts in mouse are extremely sensitive to 
a

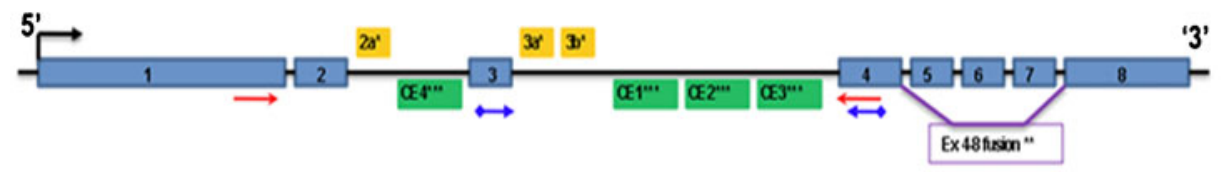

b

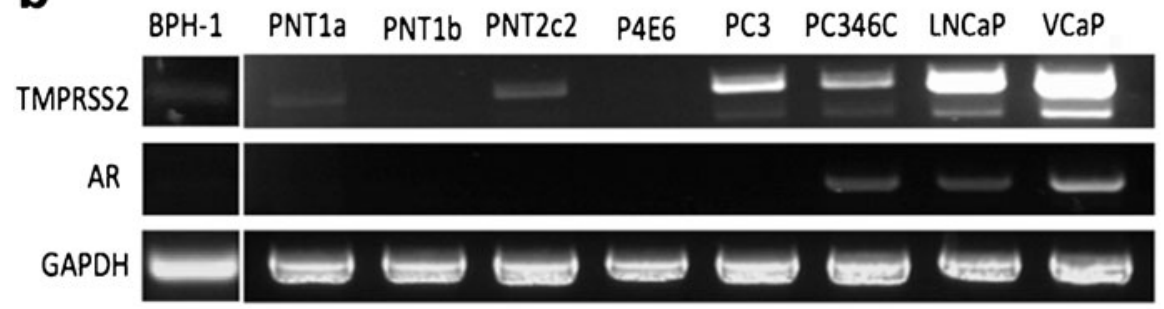

C

\begin{tabular}{|c|c|c|}
\hline \multicolumn{3}{|c|}{ Androgen Receptor } \\
\hline Sample & Fold change & Ava Ct \\
\hline PNT1a & 3.8 & 33.3 \\
\hline PNT2c2 & 5.7 & 34.2 \\
\hline BPH-1 & 23.3 & 30.7 \\
\hline P4E6 & 3.7 & 33.9 \\
\hline PC3 & 1.0 & 36.3 \\
\hline LNCaP & 204820.4 & 20.6 \\
\hline VCaP & 506780.0 & 17.8 \\
\hline
\end{tabular}

\begin{tabular}{|c|c|c|}
\hline \multicolumn{3}{|c|}{ TMPRSS2 } \\
\hline Sample & Fold change & Ava Ct \\
\hline PNT1a & 1.0 & 33.1 \\
\hline PNT2c2 & 10.0 & 31.3 \\
\hline BPH-1 & 10.0 & 29.8 \\
\hline P4E6 & 5.9 & 31.2 \\
\hline PC3 & 314.7 & 26.0 \\
\hline LNCaP & 34756.6 & 21.1 \\
\hline VCaP & 2264.5 & 23.5 \\
\hline
\end{tabular}

d
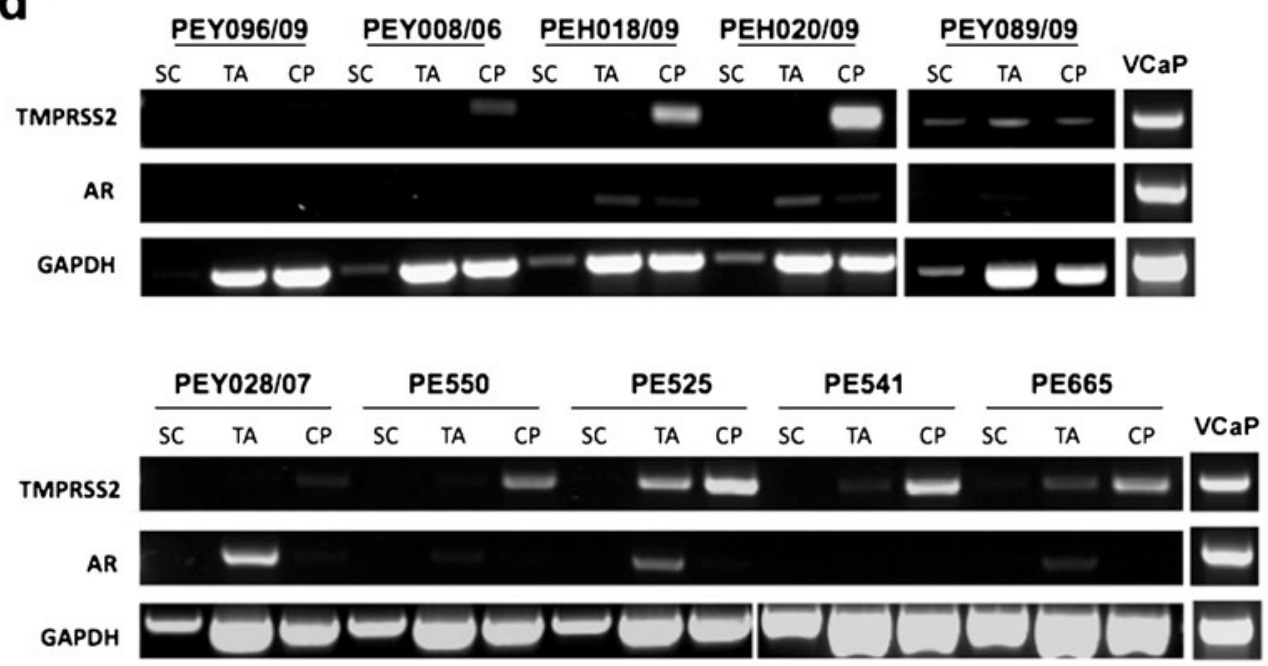

androgens, whereas the proximal regions are not so strictly androgen dependent [62]. The murine acinar structures are also much simpler, with relatively few basal cells and a less complex and less abundant stroma. Prostate regeneration after relief of castration is also simpler and more reproducible in murine prostate [63].

There is also good evidence in favor of an androgenresponsive cell initiating experimental murine prostate cancer, to the extent that the androgen receptor has been termed an oncogene in mouse prostate [64]. There are a number of transgenic cancer models in which the initiating event is, for example, probasin activation of a potent oncogene, such as T antigen from SV40 [65], or probasin directed cre mediated knockout of a potent tumor suppressor like PTEN [66]. As probasin is a secreted rat product [52], it has naturally been assumed that probasin is 
Fig. 6 Estrogen receptor transcription in fractionated prostate epithelial cells. a ER expression detected by RT-PCR in prostate epithelial cell lines. b ER expression detected by RT-PCR in fractionated primary prostate epithelial cells. Semiquantitative PCR was carried out as described in [42] a

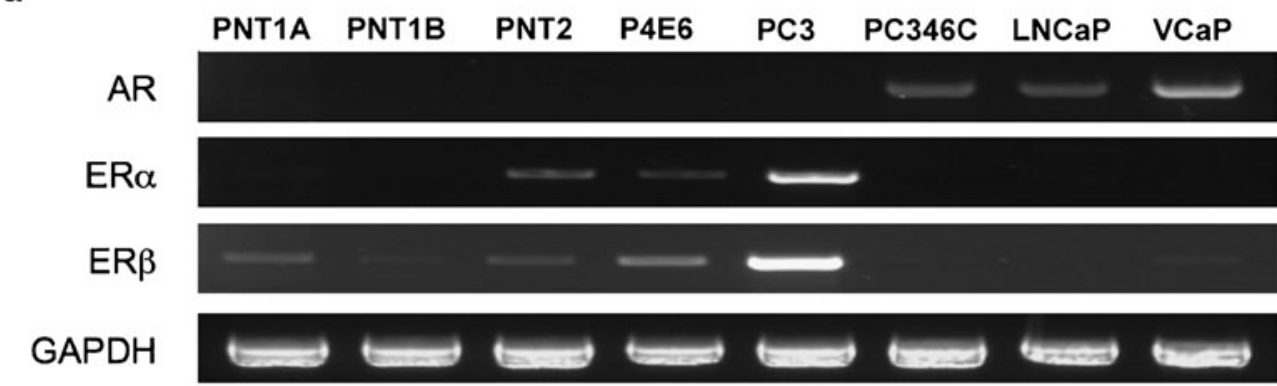

b +ve control

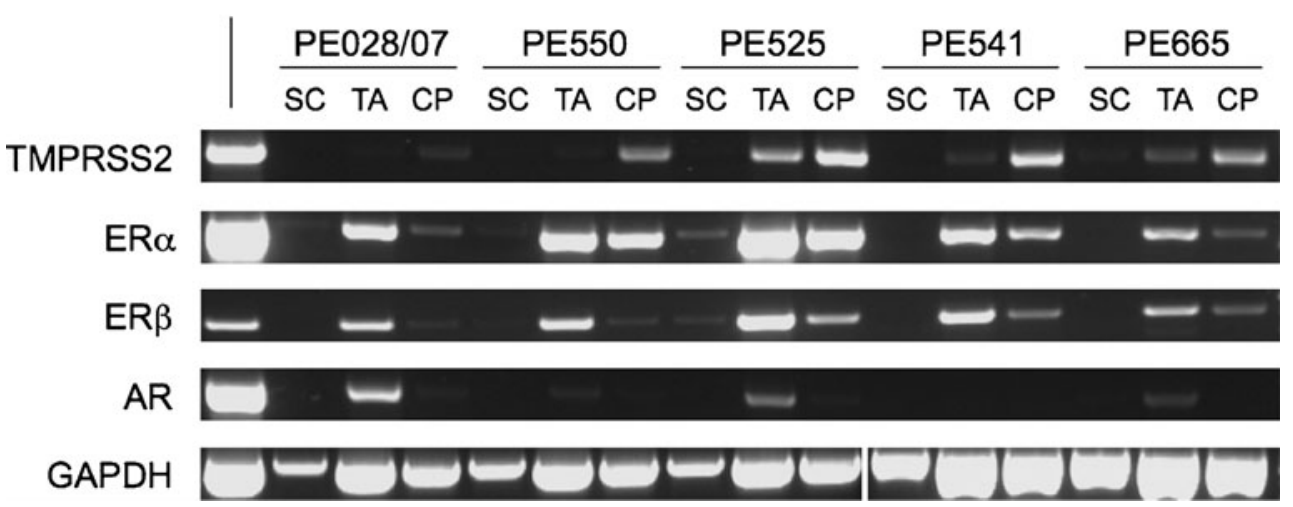

luminally restricted (and androgen regulated), but in a similar manner to the TMPRSS2 gene expression described above [12], AR regulation is rarely on-off, and the transition from basal to luminal expression is frequently a substantial up-regulation from a lower level expression. Transition may be the key term when describing prostate epithelial cell hierarchy [45] since it is less likely to be a single precise switch from one cell type to another and more of a continuum with different stages of change.

On the contrary, more recently, using a precise PTEN knockout mouse, Liao et al. [67] showed that not only was the phenotype of the initiating cell modified by the microenvironment but that the tumor-initiating cell also expressed the strongly basal p63 marker [46]. While the requirement for $\mathrm{p} 63$ for prostate development remains somewhat controversial $[46,68]$, these mouse experiments probably confirm its essential role, as in other epithelial tissues. In human epithelium, p63 is expressed strongly in basal epithelium and is also present in less than $1 \%$ of epithelial cells in human tumors, but enriched in vitro (Fig. 2). This low percentage is probably below that detectable by gross immunohistology where tumors are often 100\% p63 "negative": a feature often used for immunodiagnosis [69]. Clusters of cells expressing p63 (Fig. 7a) were also apparent in our xenografted tumors after lineage depletion.

In humans, although the markers to select normal and malignant epithelial stem cells from prostate are still somewhat varied [28-30, 34-39, 70-74], there now seems to be a greater consensus pointing towards a basal cell as the necessary initiator of glandular growth. In all cases, both integrins and the CD44 cell surface antigen [34, 37, $71,73,74]$ are represented in the normal human epithelial stem cell phenotype. However, in our laboratory, we found that cells selected even by a combination of such antigens remained heterogeneous, and that not all selected cells were clonogenic or gland initiating in immunocompromised mouse grafts (Tables 1, 2, and 3). Further fractionation was possible with antibodies against the common ("stem cell") CD133 antigen [31], specifically those directed against the AC133 epitope. However, CD133 expression is a complex procedure [41]. The variable expression of CD133 provides an excellent example of the adaptability in gene expression, even phenotypic plasticity, which might be required of a successful stem cell, in order to respond to changes in its microenvironment.

Our experimental procedure to isolate potential cancer stem cells from prostate involved dissociation of primary tissue biopsies originally taken by thick needle dissection of radical prostatectomy from areas of clearly identifiable viable tumor origin. Benign comparisons were taken either from normal areas of the same prostate, resections for cystectomy, or more commonly transurethral resections of benign prostatic hyperplasia. The procedure was invariably biased in favor of more primitive basal cells since the growth medium [34] was serum-free and based on a similar 
a

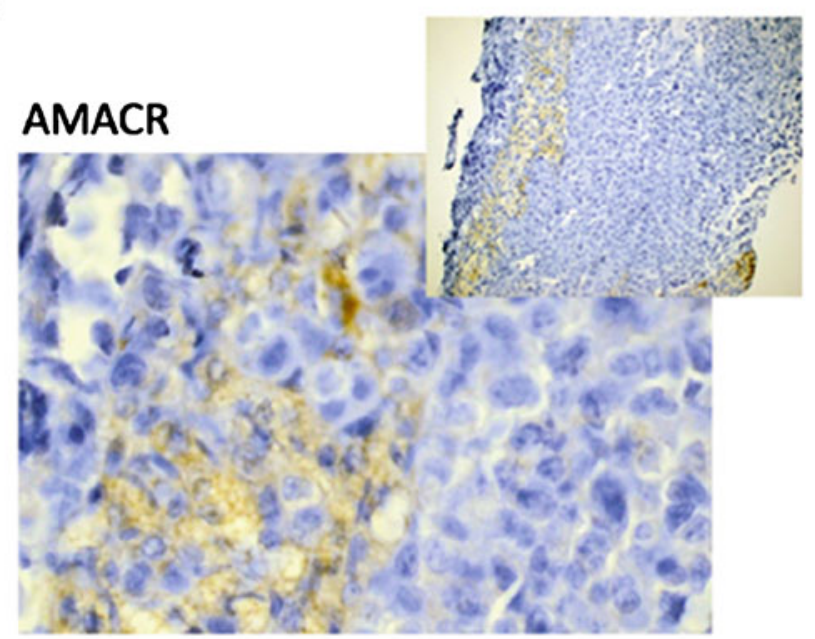

P63

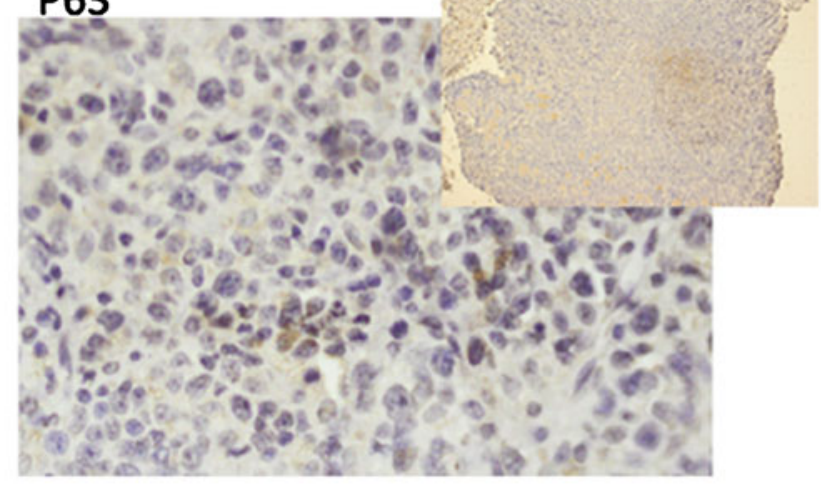

b
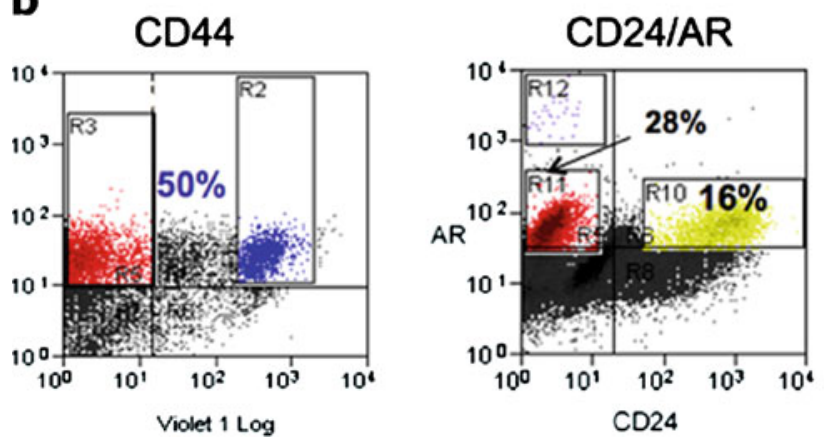

Fig. 7 Immunophenotype of prostate xenograft tumors derived from SC fractions. a Immunohistology of serially xenografted tumors derived from lineage-depleted prostate basal epithelial cells. Note focal expression of tumor (AMACR), basal (P63), and luminal markers (AR and $P S A$ ) from an originally basal cell population. b FACS

medium to propagate embryonic stem cells in colony form. In addition, the cells were cultured on a collagen substrate in the presence of irradiated STO feeders. With hematopoietic stem cells for example, this has been highly successful, but with solid tumors the conditions for such differentiation both in vitro and in vivo are almost certainly more demanding. Hence, any cultures would be expected to be
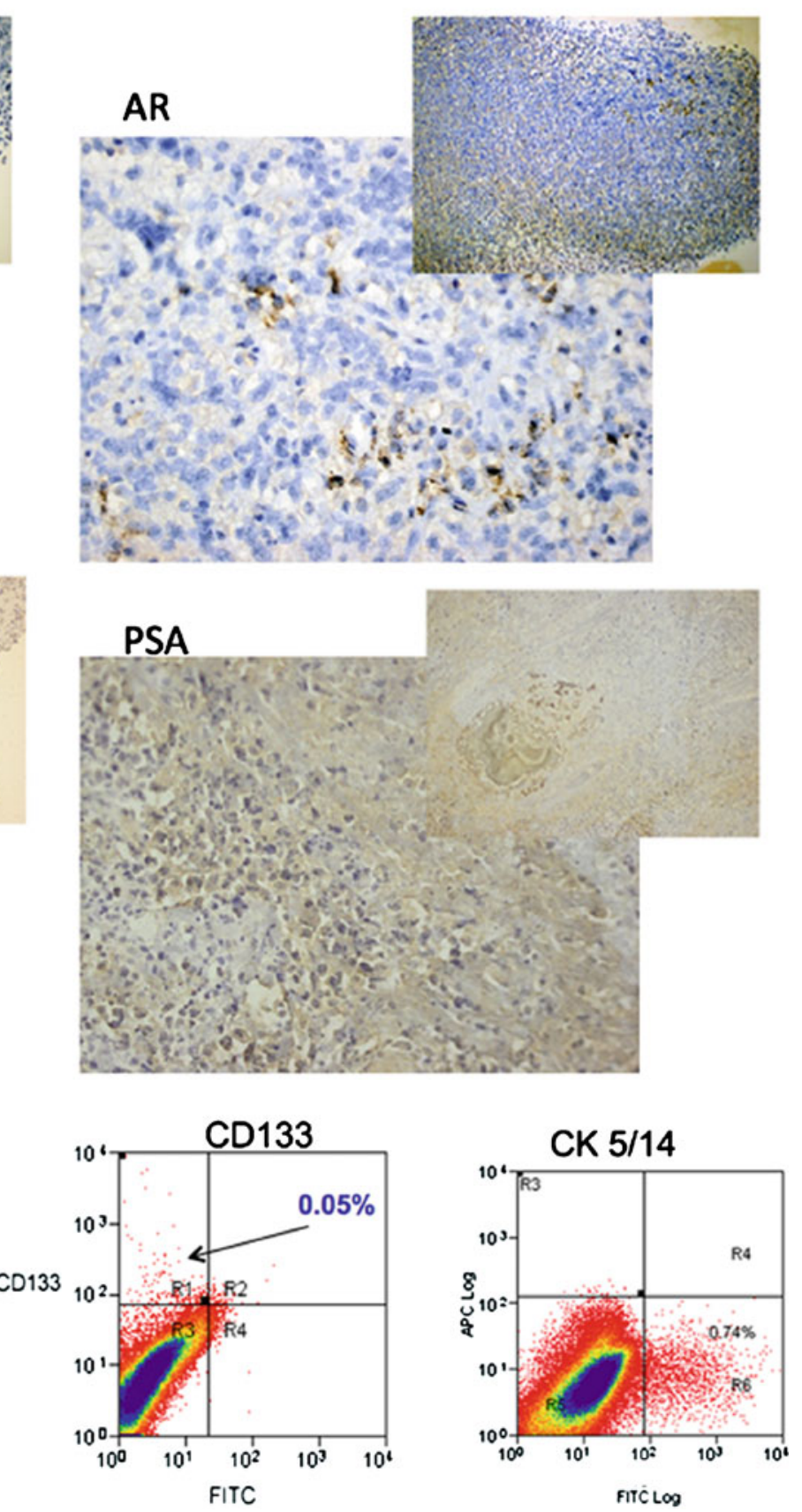

analysis of disaggregated xenograft tumors is indicative of an intermediate differentiation phenotype, with a consistent and low content of primitive basal cells. Left to right: CD44 (50\% of cells); AR (44\% of cells); high CD24 ${ }^{+} \mathrm{AR}(16 \%)$; CD133 (0.05\%); basal cytokeratins $5 / 14(0.74 \%)$

heavily biased towards the proliferation of primitive basal cells. From the data presented earlier, it is clear that these cells, from non-malignant prostate, retain the ability to regenerate glandular structures in vivo (in the presence of matrigel and prostate stroma) and can recapitulate the transition from basal to luminal cell in response to external stimuli, as shown by the lineage tracking lentiviral vectors [44]. An alternative, 
Table 2 Xenograft frequency with lineage-depleted and fractionated epithelial cells from prostate cancers: tumor incidence after subcutaneous xenografts with serially diluted cell populations

\begin{tabular}{lllll}
\hline Cell population & \multicolumn{3}{l}{ No. tumors/no. grafted } \\
\cline { 2 - 5 } & \multicolumn{2}{l}{ No. cells/graft (latency) } \\
\cline { 2 - 5 } & $10^{5}$ & $10^{4}$ & $10^{3}$ & $10^{2}$ \\
\hline Unsorted & $4 / 4(40)$ & $2 / 2(35)$ & $0 / 2$ & $0 / 2$ \\
${\text { CD } 44^{+}}_{\mathrm{CD} 133^{+}}^{2 / 2(45)}$ & - & - & - \\
$\mathrm{CD} 24^{+}$ & - & $1 / 2(50)$ & $1 / 4(92)$ & $1 / 4(163)$ \\
\hline
\end{tabular}

stepwise approach involving the putative basal SC from human prostate tissues multiply transfected with activating genes has recently demonstrated that basal cells can indeed serve as the origin of a tumor xenograft [39].

When identifying the molecular phenotype of the cancer stem cell in prostate cancer, the heterogeneous nature of the disease and the incomplete state of knowledge concerning the epithelial differentiation program in prostate, relative to other epithelial tissues and in particular hematopoiesis, has resulted in a number of potential CSC candidates. Based on earlier studies with non-malignant prostate, we reasoned that the CSC should share at least some of the antigenic phenotype [34]. However, prostate cancers are notoriously difficult to maintain in cell culture. There are relatively few new convincing cell lines, and those derived from primary xenografts in immunocompromised mice are generally from castration resistant patients' tumors [75, 76].

In human cells, there are also a number of experimental reports which have implicated androgens as a powerful initiator of prostate cancer, and this would imply that the tumor-initiating cell itself would be $\mathrm{AR}^{+}$or at least $\mathrm{AR}$ responsive [27]. As tumor initiation cannot be modeled in humans, all such studies have been reliant on either cell line models or a retrospective analysis of established human tumors [70]. The ability of human androgen receptor to generate chromosomal deletions, and to activate an oncogenic phenotype, i.e., to act as an oncogene, has also been shown recently $[15,16,64]$.
The lack of structure within the tumor mass of our xenografts is typical of mouse xenografts [75, 76] of prostate cancer. The prostate cancer SCs bear comparison to cancer stem cells from both hematopoietic malignancies and solid tumors. Although the stem cell markers may be different, the assays and characteristics can reveal important similarities as well as other differences. In breast cancers, another hormone-responsive cancer like prostate, the $\mathrm{CD} 44^{+} / \mathrm{CD} 24^{\text {low }}$ cell—a basal cell-is responsible for tumor induction [77].

We therefore conclude that cells with a primitive, largely basal phenotype can be purified from hormone naïve primary human prostate cancers. These cells have a unique phenotype distinct from different classes of differentiated progeny [42], are capable of self-renewal, and can be serially transplanted (but without in vitro culture) into immunocompromised mice. Fewer than 100 cells with the CSC phenotype can initiate new tumor growth, which has an intermediate/para-luminal $\mathrm{AR}^{+}$phenotype, even in the absence of human prostatic stromal cells. The secondary tumors retain the critical CSC phenotype in a reproducibly small proportion of cells (Fig. 7).

\section{Conclusions}

Looking to the future, further investigations into the definition, characterization, and functions of a prostate (cancer) SC will enhance our knowledge of prostate epithelial hierarchy as well as tumor initiation properties. It may be that our definitions of these cells will become less strict since there is likely to be heterogeneity within populations and indeed plasticity within individual cells, which may depend on external signals and their niche. The researchers in this field may also have to follow cell fate dynamically and remain flexible and fluid in their conclusions depending on new findings that occur. When defining cells by specific markers, it is acknowledged that each marker defines a snapshot of a particular cell in a certain environment with external stimuli at a moment in time. This is clearly a large leap forward from analyzing a tumor as a whole, and our ability to dissect populations of
Table 3 Xenograft frequency with lineage-depleted and fractionated epithelial cells from prostate cancers: tumorigenicity of serially diluted, lineagedepleted and sub-fractionated cell populations in the immunocompromised mouse assay, resulting in an estimate of the frequency of tumor-initiating cells in various populations

\begin{tabular}{|c|c|c|c|c|c|c|c|c|}
\hline \multirow[t]{3}{*}{ Phenotype } & \multicolumn{7}{|c|}{ Number of tumors/number of injections } & \multirow[t]{3}{*}{ Tumor-initiating frequency $(95 \% \mathrm{CI})$} \\
\hline & \multicolumn{7}{|c|}{ Cells per injection } & \\
\hline & $10^{2}$ & $10^{3}$ & $5 \times 10^{3}$ & $10^{4}$ & $5 \times 10^{4}$ & $10^{5}$ & $10^{6}$ & \\
\hline $\mathrm{hLin}^{-}$ & - & - & - & $2 / 2$ & - & $1 / 1$ & $2 / 4$ & $1 / 10^{5}\left(1 / 10^{5}-1 / 10^{6}\right)$ \\
\hline $\mathrm{CD} 24^{+}$ & $0 / 1$ & - & $1 / 1$ & $1 / 1$ & $1 / 1$ & $1 / 1$ & - & $1 / 10^{3}\left(1 / 10^{1}-1 / 10^{4}\right)$ \\
\hline $\mathrm{CD}_{133^{+}}$ & $1 / 2$ & $2 / 2$ & - & $1 / 2$ & - & - & - & $1 / 10^{2}\left(1 / 10^{0}-1 / 10^{2}\right)$ \\
\hline
\end{tabular}


cells from a heterogeneous mixture is key to stem cell research, although probably no marker is perfect. Ultimately, progress must lead us to a therapy-approached investigation. The current cancer stem cell revolution should lead to demonstrable patient benefit in terms of identification of novel drug targets and development of new drugs to combat prostate cancer in all its forms.

Acknowledgments The authors thank the Roger Tsien laboratory (University of California San Diego) for the gift of pRSETBmOrange, pRSETBtdTomato, and pRSETBmCitrine, Dr. Jan Trapman (EMC, Rotterdam) for providing the PSAPb promoter, and Dr. Simon Hayward (Vanderbilt University, Nashville, TN) for provision of the BPH-1 cells. The clinical material was supplied by Mike Stower (York) and Matt Simms (Hull). This work was supported by Yorkshire Cancer Research.

Conflict of Interest The authors declare that they have no conflict of interest.

\section{References}

1. Maitland NJ (2008) Pathobiology of the human prostate. Trends Urol Gynaecol Sex Health 13:12-19

2. Gutman EB, Sproul EE, Gutman AB (1936) Significance of increased phosphatase activity of bone at the site of osteoblastic metastases secondary to carcinoma of the prostate gland. Am J Cancer 28:485-495

3. Vickers AJ, Cronin AM, Roobol MJ, Hugosson J, Jones JS, Kattan MW, Klein E, Hamdy F, Neal D, Donovan J, Parekh DJ, Ankerst D, Bartsch G, Klocker H, Horninger W, Benchikh A, Salama G, Villers A, Freedland SJ, Moreira DM, Schröder FH, Lilja H (2010) The relationship between prostate-specific antigen and prostate cancer risk: the Prostate Biopsy Collaborative Group. Clin Cancer Res 16(17):4374-4381

4. Armstrong AJ, Garrett-Mayer E, de Wit R, Tannock I, Eisenberger M (2010) Prediction of survival following first-line chemotherapy in men with castration-resistant metastatic prostate cancer. Clin Cancer Res 16(1):203-211

5. Miller GJ, Cygan JM (1994) Morphology of prostate cancer: the effects of multifocality on histological grade, tumor volume and capsule penetration. J Urol 152:1709-1713

6. Sadi MV, Barrack ER (1993) Image analysis of androgen receptor immunostaining in metastatic prostate cancer. Heterogeneity as a predictor of response to hormonal therapy. Cancer 71:2574-2803

7. Ruijter ET, Miller GJ, van de Kaa CA et al (1999) Molecular analysis of multifocal prostate cancer lesions. J Pathol 18:271-277

8. Lydiatt WM, Anderson PE, Bazzana T, Casale M, Hughes CJ, Huvos AG, Lydiatt DD, Schantz SP (1998) Molecular support for field cancerization in the head and neck. Cancer 82(7):1376-1380

9. Macintosh CA, Stower M, Reid N, Maitland NJ (1998) Precise microdissection of human prostate cancers reveals genotypic heterogeneity. Cancer Res 58(1):23-28

10. Clark J, Attard G, Jhavar S, Flohr P, Reid A, De-Bono J, Eeles R, Scardino P, Cuzick J, Fisher G, Parker MD, Foster CS, Berney D, Kovacs G, Cooper CS (2008) Complex patterns of ETS gene alteration arise during cancer development in the human prostate. Oncogene 27(14):1993-2003

11. Tomlins SA et al (2005) Recurrent fusion of TMPRSS2 and ETS transcription factor genes in prostate cancer. Science 310 (5748):644-648
12. Lin B, Ferguson C, White JT, Wang S, Vessella R, True LD, Hood L, Nelson PS (1999) Prostate-localized and androgen-regulated expression of the membrane-bound serine protease TMPRSS2. Cancer Res 59(17):4180-4184

13. Tomlins SA, Laxman B, Varambally S, Cao X, Yu J, Helgeson BE, Cao Q, Prensner JR, Rubin MA, Shah RB, Mehra R, Chinnaiyan AM (2008) Role of the TMPRSS2-ERG gene fusion in prostate cancer. Neoplasia 10(2):177-188

14. Carver BS, Tran J, Gopalan A, Chen Z, Shaikh S, Carracedo A, Alimonti A, Nardella C, Varmeh S, Scardino PT, Cordon-Cardo C, Gerald W, Pandolfi PP (2009) Aberrant ERG expression cooperates with loss of PTEN to promote cancer progression in the prostate. Nat Genet 41(5):619-624

15. Mani RS, Tomlins SA, Callahan K, Ghosh A, Nyati MK, Varambally S, Palanisamy N, Chinnaiyan AM (2009) Induced chromosomal proximity and gene fusions in prostate cancer. Science 326(5957):1230

16. Lin C, Yang L, Tanasa B, Hutt K, Ju BG, Ohgi K, Zhang J, Rose DW, Fu XD, Glass CK, Rosenfeld MG (2009) Nuclear receptorinduced chromosomal proximity and DNA breaks underlie specific translocations in cancer. Cell 139(6):1069-1083

17. Bonnet D, Dick JE (1997) Human acute myeloid leukemia is organized as a hierarchy that originates from a primitive hematopoietic cell. Nat Med 3(7):730-737

18. Boman BM, Wicha MS (2008) Cancer stem cells: a step toward the cure. J Clin Oncol 26(17):2795-2799

19. Maitland NJ, Collins AT (2008) Prostate cancer stem cells: a new target for therapy. J Clin Oncol 26(17):2862-2870

20. Stanley JR, Woodley DT, Katz SI, Martin GR (1982) Structure and function of basement membrane. J Invest Dermatol 79(Suppl 1):69s-72s

21. Lang SH, Stark M, Collins A, Paul AB, Stower MJ, Maitland NJ (2001) Experimental prostate epithelial morphogenesis in response to stroma and three-dimensional matrigel culture. Cell Growth Differ 12(12):631-640

22. Yang F, Strand DW, Rowley DR (2008) Fibroblast growth factor2 mediates transforming growth factor-beta action in prostate cancer reactive stroma. Oncogene 27(4):450-459

23. Cunha GR (1984) Androgenic effects upon prostatic epithelium are mediated via trophic influences from stroma. Prog Clin Biol Res 145:81-102

24. Berry PA, Maitland NJ, Collins AT (2008) Androgen receptor signalling in prostate: effects of stromal factors on normal and cancer stem cells. Mol Cell Endocrinol 288(1-2):30-37

25. Thomson AA (2008) Mesenchymal mechanisms in prostate organogenesis. Differentiation 76(6):587-598

26. Leong KG, Wang BE, Johnson L, Gao WQ (2008) Generation of a prostate from a single adult stem cell. Nature 456(7223):804-808

27. Wang X, Kruithof-de Julio M, Economides KD, Walker D, Yu H, Halili MV, Hu YP, Price SM, Abate-Shen C, Shen MM (2009) A luminal epithelial stem cell that is a cell of origin for prostate cancer. Nature 461(7263):495-500

28. Collins AT, Habib FK, Maitland NJ, Neal DE (2001) Identification and isolation of human prostate epithelial stem cells based on alpha (2)beta(1)-integrin expression. J Cell Sci 114(Pt 21):3865-3872

29. Garraway IP, Sun W, Tran CP, Perner S, Zhang B, Goldstein AS, Hahm SA, Haider M, Head CS, Reiter RE, Rubin MA, Witte ON (2010) Human prostate sphere-forming cells represent a subset of basal epithelial cells capable of glandular regeneration in vivo. Prostate 70(5):491-501

30. Richardson GD, Robson CN, Lang SH, Neal DE, Maitland NJ, Collins AT (2004) CD133, a novel marker for human prostatic epithelial stem cells. J Cell Sci 117(Pt 16):3539-3545

31. Meregalli M, Farini A, Belicchi M, Torrente Y (2010) CD133(+) cell isolated from various sources and their role in future clinical perspectives. Expert Opin Biol Ther 10(11):1521-1528 
32. Takahashi K, Tanabe K, Ohnuki M, Narita M, Ichisaka T, Tomoda K, Yamanaka S (2007) Induction of pluripotent stem cells from adult human fibroblasts by defined factors. Cell 131:861-872

33. Yu J, Vodyanik MA, Smuga-Otto K, Antosiewicz-Bourget J, Frane JL, Tian S, Nie J, Jonsdottir GA, Ruotti V, Stewart R, Slukvin II, Thomson JA (2007) Induced pluripotent stem cell lines derived from human somatic cells. Science 318:1917-1920

34. Collins AT, Berry PA, Hyde C, Stower MJ, Maitland NJ (2005) Prospective identification of tumorigenic prostate cancer stem cells. Cancer Res 65:10946-10951

35. Patrawala L, Calhoun-Davis T, Schneider-Broussard R, Tang DG (2007) Hierarchical organization of prostate cancer cells in xenograft tumors: the CD44+alpha2beta1+ cell population is enriched in tumor-initiating cells. Cancer Res 67(14):6796-6805, Erratum in: Cancer Res. 2007 Sep 15;67(18):8973

36. Vander Griend DJ, Karthaus WL, Dalrymple S, Meeker A, DeMarzo AM, Isaacs JT (2008) The role of CD133 in normal human prostate stem cells and malignant cancer-initiating cells. Cancer Res 68(23):9703-9711

37. van den Hoogen C, van der Horst G, Cheung H, Buijs JT, Lippitt JM, Guzmán-Ramírez N, Hamdy FC, Eaton CL, Thalmann GN, Cecchini MG, Pelger RC, van der Pluijm G (2010) High aldehyde dehydrogenase activity identifies tumor-initiating and metastasisinitiating cells in human prostate cancer. Cancer Res 70(12):51635173

38. Hurt EM, Kawasaki BT, Klarmann GJ, Thomas SB (2008) Farrar WL.CD44+CD24(-) prostate cells are early cancer progenitor/ stem cells that provide a model for patients with poor prognosis. Br J Cancer 98(4):756-765

39. Lawson DA, Zong Y, Memarzadeh S, Xin L, Huang J, Witte ON (2010) Basal epithelial stem cells are efficient targets for prostate cancer initiation. Proc Natl Acad Sci USA 107(6):2610-2616

40. Platet N, Liu SY, Atifi ME, Oliver L, Vallette FM, Berger F, Wion D (2007) Influence of oxygen tension on CD133 phenotype in human glioma cell cultures. Cancer Lett 258(2):286-290

41. Shmelkov SV, St Clair R, Lyden D, Rafii S (2005) AC133/ CD133/prominin-1. Int J Biochem Cell Biol 37(4):715-719

42. Birnie R, Bryce SD, Roome C, Dussupt V, Droop A, Lang SH, Berry PA, Hyde CF, Lewis JL, Stower MJ, Maitland NJ, Collins AT (2008) Gene expression profiling of human prostate cancer stem cells reveals a pro-inflammatory phenotype and the importance of extracellular matrix interactions. Genome Biol 9 (5):R83

43. De Marzo AM, Meeker AK, Epstein JI, Coffey DS (1998) Prostate stem cell compartments. Expression of the cell cycle inhibitor $\mathrm{p} 27^{\mathrm{Kip} 1}$ in normal, hyperplastic, and neoplastic cells. Am J Pathol 153(3):911-919

44. Grisanzio C, Signoretti S (2008) p63 in prostate biology and pathology. J Cell Biochem 103(5):1354-1368

45. Luo J, Zha S, Gage WR, Dunn TA, Hicks JL, Bennett CJ, Ewing CM, Platz EA, Ferdinandusse S, Wanders RJ, Trent JM, Isaacs WB, De Marzo AM (2002) Alpha-methylacyl-CoA racemase: a new molecular marker for prostate cancer. Cancer Res 62 (8):2220-2226

46. Mani SA, Guo W, Liao MJ, Eaton EN, Ayyanan A, Zhou AY, Brooks M, Reinhard F, Zhang CC, Shipitsin M, Campbell LL, Polyak K, Brisken C, Yang J, Weinberg RA (2008) The epithelial-mesenchymal transition generates cells with properties of stem cells. Cell 133(4):704-715

47. Sarrio D, Rodriguez-Pinilla SM, Hardisson D, Cano A, MorenoBueno G, Palacios J (2008) Epithelial-mesenchymal transition in breast cancer relates to the basal-like phenotype. Cancer Res 68 (4):989-997

48. Lang SH, Hyde C, Reid IN, Hitchcock IS, Hart CA, Gordon Bryden AA, Villette JM, Stower MJ, Maitland NJ (2002) Enhanced expression of vimentin in motile prostate cell lines and in poorly differentiated and metastatic prostate carcinoma. Prostate 52:253-263

49. Hager S, Frame FM, Collins AC, Burns JE, Maitland NJ (2008) An internal polyadenylation signal substantially increases expression levels of lentivirus-delivered transgenes but has the potential to reduce virus titre in a promoter-dependent manner. Hum Gene Ther 19:840-850

50. Frame FM, Hager S, Pellacani D, Stower MJ, Walker HF, Burns JE, Collins AT, Maitland NJ (2010) Development and limitations of lentivirus vectors as tools for tracking differentiation in prostate epithelial cells. Exp Cell Res 316(19):3161-3171

51. Kraaij R, van der Weel L, de Ridder CM, van der Korput HA, Zweistra JL, van Rijswijk AL, Bangma CH, Trapman J (2007) A small chimeric promoter for high prostate-specific transgene expression from adenoviral vectors. Prostate 67(8):829-839

52. Yan Y, Sheppard PC, Kasper S, Lin L, Hoare S, Kapoor A, Dodd JG, Duckworth ML, Matusik RJ (1997) Large fragment of the probasin promoter targets high levels of transgene expression to the prostate of transgenic mice. Prostate 32(2):129-139

53. Swift SL, Burns JE, Maitland NJ (2010) Altered expression of neurotensin receptors is associated with the differentiation state of prostate cancer. Cancer Res 70(1):347-356

54. Guo Z, Yang X, Sun F, Jiang R, Linn DE, Chen H, Chen H, Kong X, Melamed J, Tepper CG, Kung HJ, Brodie AM, Edwards J, Qiu $\mathrm{Y}$ (2009) A novel androgen receptor splice variant is up-regulated during prostate cancer progression and promotes androgen depletion-resistant growth. Cancer Res 69(6):2305-2313

55. Hu R, Dunn TA, Wei S, Isharwal S, Veltri RW, Humphreys E, Han M, Partin AW, Vessella RL, Isaacs WB, Bova GS, Luo J (2009) Ligand-independent androgen receptor variants derived from splicing of cryptic exons signify hormone-refractory prostate cancer. Cancer Res 69(1):16-22

56. Sun S, Sprenger CC, Vessella RL, Haugk K, Soriano K, Mostaghel EA, Page ST, Coleman IM, Nguyen HM, Sun H, Nelson PS, Plymate SR (2010) Castration resistance in human prostate cancer is conferred by a frequently occurring androgen receptor splice variant. J Clin Invest 120(8):2715-2730

57. McPherson SJ, Hussain S, Balanathan P, Hedwards SL, Niranjan B, Grant M, Chandrasiri UP, Toivanen R, Wang Y, Taylor RA, Risbridger GP (2010) Estrogen receptor-beta activated apoptosis in benign hyperplasia and cancer of the prostate is androgen independent and TNFalpha mediated. Proc Natl Acad Sci USA 107(7):3123-3128

58. Setlur SR, Mertz KD, Hoshida Y, Demichelis F, Lupien M, Perner S, Sboner A, Pawitan Y, Andrén O, Johnson LA, Tang J, Adami HO, Calza S, Chinnaiyan AM, Rhodes D, Tomlins S, Fall K, Mucci LA, Kantoff PW, Stampfer MJ, Andersson SO, Varenhorst E, Johansson JE, Brown M, Golub TR, Rubin MA (2008) Estrogen-dependent signaling in a molecularly distinct subclass of aggressive prostate cancer. J Natl Cancer Inst 100(11):815825

59. Goldstein AS, Huang J, Guo C, Garraway IP, Witte ON (2010) Identification of a cell of origin for human prostate cancer. Science 329(5991):568-571

60. Collins AT, Maitland NJ (2009) Prostate cancer: regeneration of interest in the prostate. Nat Rev Urol 6(4):184-186

61. Seita J, Weissman IL (2010) Hematopoietic stem cell: self-renewal versus differentiation. Wiley Interdiscip Rev Syst Biol Med 2 (6):640-653

62. Sugimura Y, Cunha GR, Donjacour AA (1986) Morphological and histological study of castration-induced degeneration and androgen-induced regeneration in the mouse prostate. Biol Reprod 34(5):973-983

63. Fink D, Fazli L, Aronow B, Gleave ME, Ong CJ (2006) Clusterin is not essential for androgen-regulated involution and regeneration of the normal mouse prostate. Prostate 66(13):1445-1454 
64. Han G, Buchanan G, Ittmann M, Harris JM, Yu X, Demayo FJ, Tilley W, Greenberg NM (2005) Mutation of the androgen receptor causes oncogenic transformation of the prostate. Proc Natl Acad Sci USA 102(4):1151-1156

65. Greenberg NM, DeMayo F, Finegold MJ, Medina D, Tilley WD, Aspinall JO, Cunha GR, Donjacour AA, Matusik RJ, Rosen JM (1995) Prostate cancer in a transgenic mouse. Proc Natl Acad Sci USA 92(8):3439-3443

66. Mulholland DJ, Xin L, Morim A, Lawson D, Witte O, Wu H (2009) Lin-Sca-1+ CD49fhigh stem/progenitors are tumorinitiating cells in the Pten-null prostate cancer model. Cancer Res 69(22):8555

67. Liao CP, Adisetiyo H, Liang M, Roy-Burman P (2010) Cancerassociated fibroblasts enhance the gland-forming capability of prostate cancer stem cells. Cancer Res 70(18):7294-7303

68. Kurita T, Medina RT, Mills AA, Cunha GR (2004) Role of p63 and basal cells in the prostate. Development 131:4955-4964

69. Weinstein MH, Signoretti S, Loda M (2002) Diagnostic utility of immunohistochemical staining for p63, a sensitive marker of prostatic basal cells. Mod Pathol 15(12):1302-1308

70. Vander Griend DJ, D'Antonio J, Gurel B, Antony L, Demarzo AM, Isaacs JT (2010) Cell-autonomous intracellular androgen receptor signaling drives the growth of human prostate cancer initiating cells. Prostate 70(1):90-99

71. Shepherd CJ, Rizzo S, Ledaki I, Davies M, Brewer D, Attard G, de Bono J, Hudson DL (2008) Expression profiling of CD133+ and CD133- epithelial cells from human prostate. Prostate 68 (9):1007-1024

72. Li H, Chen X, Calhoun-Davis T, Claypool K, Tang DG (2008) PC3 human prostate carcinoma cell holoclones contain selfrenewing tumor-initiating cells. Cancer Res 68(6):1820-1825

73. Patrawala L, Calhoun T, Schneider-Broussard R, Li H, Bhatia B, Tang S, Reilly JG, Chandra D, Zhou J, Claypool K, Coghlan L, Tang DG (2006) Highly purified CD44+ prostate cancer cells from xenograft human tumors are enriched in tumorigenic and metastatic progenitor cells. Oncogene 25 (12):1696-1708

74. Gu G, Yuan J, Wills M, Kasper S (2007) Prostate cancer cells with stem cell characteristics reconstitute the original human tumor in vivo. Cancer Res 67(10):4807-4815

75. van Weerden WM, Bangma C, de Wit R (2009) Human xenograft models as useful tools to assess the potential of novel therapeutics in prostate cancer. Br J Cancer 100(1):13-18

76. Wang Y, Xue H, Cutz JC, Bayani J, Mawji NR, Chen WG, Goetz LJ, Hayward SW, Sadar MD, Gilks CB, Gout PW, Squire JA, Cunha GR, Wang YZ (2005) An orthotopic metastatic prostate cancer model in SCID mice via grafting of a transplantable human prostate tumor line. Lab Invest 85 (11):1392-1404

77. Al-Hajj M, Wicha MS, Benito-Hernandez A, Morrison SJ, Clarke MF (2003) Prospective identification of tumorigenic breast cancer cells. Proc Natl Acad Sci USA 100(7):3983-3988 